\title{
Redifferentiating Thyroid Cancer: Selumetinib-enhanced Radioiodine Uptake in Thyroid Cancer
}

\author{
Tiroid Kanser Re-diferansiyasyonu: Tiroid Kanserinde Selumetinib ile Uyarılmıs Radyoaktif \\ lyot Tutulumu
}

\author{
Steven M. Larson, Joseph R. Osborne, Ravinder K. Grewal, R. Michael Tuttle
}

Memorial Sloan Kettering Cancer Center, New York, USA

"All happy families are alike; every unhappy family is unhappy in its own way". L. Tolstoy, from Anna Karenina, quoted by John Kuniyan (U.C. Berkeley), while discussing early TKI inhibitor drugs.

\begin{abstract}
In a recent article, we reported a restorative therapeutic intervention that turned individual thyroid cancer lesions into more efficient tissues for taking up radioactive iodine (RAI), resulting in clinically significant and durable responses. A group of lodine-131 refractory thyroid cancer patients were treated with the MEK tyrosine kinase inhibitor (TKI) selumetinib, and RAI uptake was restored in a subset of patients. We employed lodine-124 positron emission tomography to measure radiation absorbed dose, on a lesion by lesion basis. The process can be thought of as a re-differentiation of the cancer toward a more nearly normal state most like the tissue from which the cancer arose. Remarkably, in its own way, a change was detected within a few weeks of treatment, restoring uptake with therapeutically effective levels of RAl and in some patients, previously completely refractory to radioiodine treatment. In this article, we summarize the basic work that led to this seminal study, and make the case for lesional dosimetry in thyroid cancer with lodine-124 as a new optimal radiotracer for precision medicine in patients with well differentiated thyroid cancer.
\end{abstract}

Keywords: Redifferentiation, thyroid cancer, selumetinib, radioiodine

\section{Öz}

Yakın tarihli bir yayında bireysel tiroid kanseri lezyonlarını radyoaktif iyot (RAi) tutulumu açısından daha etkin dokulara çeviren ve klinik olarak anlamlı ve kalıcı cevaba yol açan restoratif terapötik bir girişim bildirdik. Bir grup lyot-131 refrakter tiroid kanseri hastası MEK tirozin kinaz inhibitörü selumetinib ile tedavi edildi ve bir kısım hastada RAI tutulumu sağlandı. Lezyon-lezyona temelinde lyot-124 pozitron emisyon tomografisi ile abzorbe edilen radyasyon dozunu ölçtük. Bu işlem kanserin, ilk çıktığı dokudaki normal duruma yakın bir hale re-diferansiyasyonu olarak düşünülebilir. Illgi çekici bir şekilde birkaç hafta tedavi ile öncesinde tamamen RAi tedavisine refrakter olan bazı hastalarda terapötik olarak efektif dozlarda RAi tutulumu sağlandı. Bu makalede, bu çığır açıı temel çalışma özetlenmekte ve iyi diferansiye tiroid kanser hastalarında tedavi için yeni bir optimal radyofarmasötik olarak tiroid kanserinde lezyonel dozimetri için lyot-124 kullanımı sunulmaktadır.

Anahtar kelimeler: Re-diferansiyasyon, tiroid kanseri, selumetinib, radyoaktif iyot

Address for Correspondence: Steven M. Larson MD, Memorial Sloan Kettering Cancer Center, New York, USA Phone: 646888359 E-mail: larsons@mskcc.org

${ }^{\circ}$ Copyright 2017 by Turkish Society of Nuclear Medicine Molecular Imaging and Radionuclide Therapy published by Galenos Yayınevi. 


\section{Introduction}

If we think of a tissue with cancer as an unhappy family of interacting cells (in contrast to the "happy" well differentiated normal tissue), we begin to understand that the sad fact of malignant change can truly occur in many ways. Often, the culprits are diverse changes in the genetic code, which are now understood to be the basis for a significant number of common cancers in man. These cancer-causing genes, "oncogenes," may transform cells from normal to malignant by simple alterations in base sequences that are, in turn, transformed into alterations in the protein product of the oncogene. When a mutation is the cause of the malignant transformation, this genetic change is called a "driver oncogene." The tissue affected is said to be "oncogene-addicted" and is found when growth and even viability are dependent on the presence and continuous activity of the oncoprotein product of the specific mutation. Specific oncogenes have been identified in lung cancer, breast cancer, lymphomas, leukemias, and pediatric cancers. With regard to thyroid cancer, knowledge about the genetic lesions associated with papillary thyroid cancer has increased enormously, in the last few years. More than $95 \%$ of the driver oncogene mutations are known, and $75 \%$ of these mutations occur in the mitogenactivated protein (MAP) kinase signal transduction pathway (Figure 1).

\section{Integrated Genomic Characterization of Papillary Thyroid Carcinoma}

Effector molecules such as MEK, which in turn signal ERK, indirectly promote cellular proliferation and growth and accompany the de-differentiation of the thyroid cell, driving it to take on the properties of neoplasia. For thyroid cancer, this means a down regulation of key mature tissue functions such as iodine uptake and the formation of thyroid hormone, as the tumor cell "goes primitive" and develops a new phenotype of sustained growth and metastasis.

\section{Pre-clinical Observations Setting the Stage for Re- induction Therapy}

The genetic mutation in the BRAF gene encodes the serine/ threonine signal transduction molecule BRAF (v-raf murine sarcoma viral oncogene homolog $B 1$ ), resulting in amino acid transformation at the 600 locus in the BRAF protein. This transformation occurs as the "driver mutation" in about $40 \%$ of thyroid cancers, and about $70 \%$ of melanomas. $B R A F$ is actually an enzyme member of a signal transduction pathway, and it is this enzymatic function that transmits a message by activating through phosphorylation, the next protein in sequence, MEK [Text Box 1] (Figure 2).

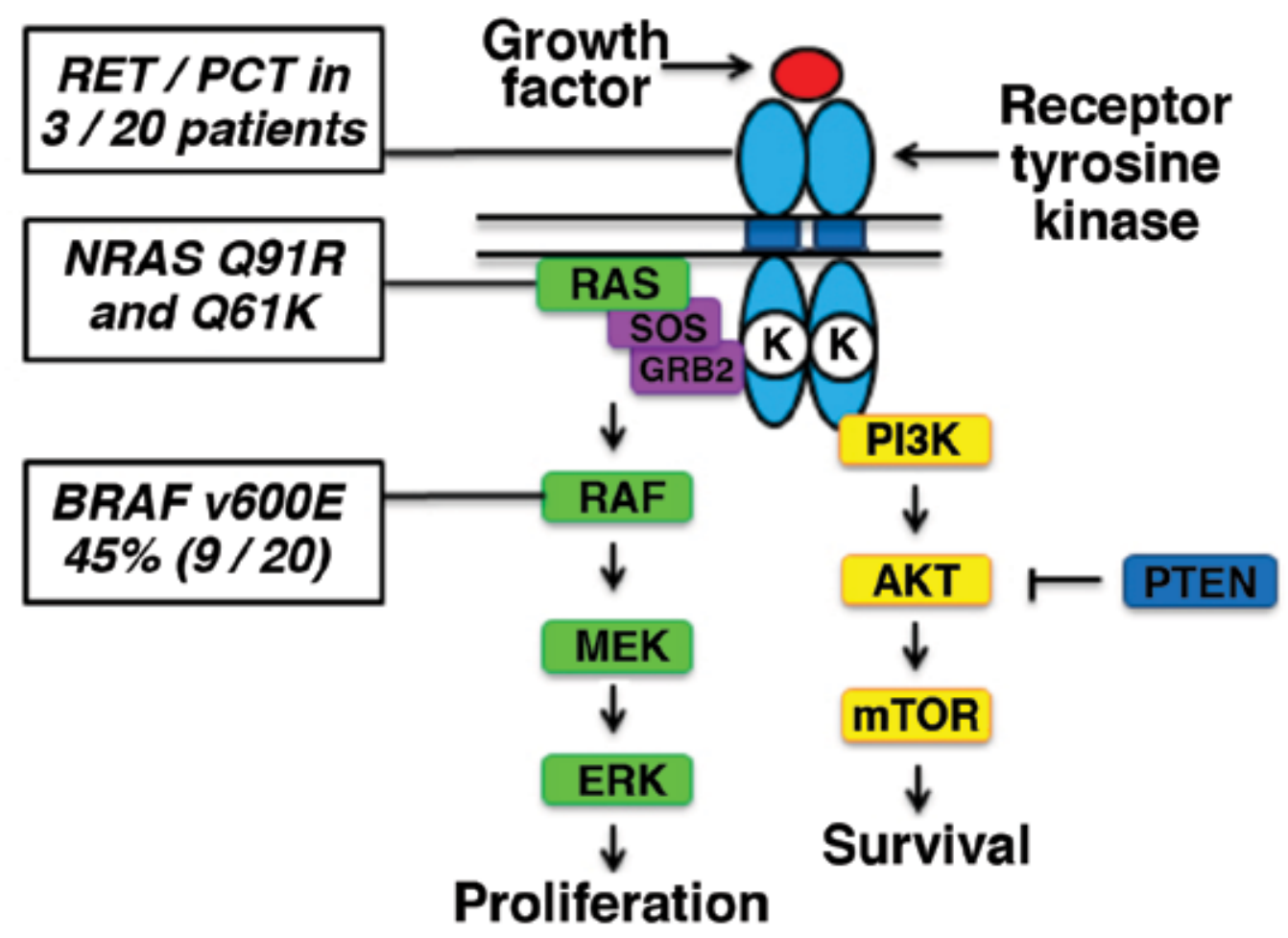

Figure 1. Mitogen-activated protein kinase signaling in papillary thyroid carcinoma is depicted along with statistical information regarding mutations and specifications at distinct points on the pathway. (Courtesy of James A. Fagin and Alan L. Ho, Memorial Sloan Kettering Cancer Center.) 
My colleagues at Memorial Sloan Kettering Cancer Center developed a mouse model for thyroid cancer in order to study the effect of the BRAF driver oncogene on a molecular basis and its role in creating the tumor phenotype. The mouse model was transgenic, in which thyroid follicular cells were induced to carry a BRAF (V600E) mutation that could be activated by treatment with doxycycline. Under treatment of these special mice with doxycycline, the thyroid of the mice transformed to take on the characteristics of a poorly differentiated thyroid cancer, for example, losing the ability to take up radioactive iodine. In their seminal paper, the authors noted the following: "Strikingly, treatment with the MAPK pathway inhibitors rendered the tumor cells susceptible to a therapeutic dose of radioactive iodine. Our data show that thyroid tumors carrying BRAFVG00E mutations are exquisitely dependent on the oncoprotein for viability and that genetic or pharmacological inhibition of its expression or activity is associated with tumor regression and restoration of radioactive iodine uptake in vivo in mice. These findings have potentially significant clinical ramifications" (Figure 2) (2).
Inhibitor drugs that block the activity of this "driver oncogene," particularly in melanoma, have been developed and widely used, greatly benefiting select cases of advanced melanoma (3). This class of medications, called tyrosine kinase inhibitor drugs, or TKIs, act by blocking the enzymatic activity of a signal transduction protein. Examples include vemurafinib to block $B-R A F$ directly and selumetinib as a blocker of the downstream MEK activity. Using this logic, the team of Chakravarty et al. (2) demonstrated proof of principle that inhibition of the MAPK pathway in the transgenic model of mutant BRAFinduced thyroid cancer partially restored radioactive iodine (RAI) uptake mechanisms within the cancer cell, sufficient to both increase RAl uptake and prolong retention in the cell. The effects were sufficient to achieve a major treatment effect on mouse thyroid cancer. This finding led to the extension of this approach to man, described in more detail below.

One feature of the preclinical paper described above was the rapid effect of the mutant BRAF gene induction on transformation of the thyroid cell into a de-differentiated state. Similarly, pharmacologic effects were also diffused and nonfocal when restoring features of the differentiated state. This

\section{Tg-rTTA/tet0-Braf ${ }^{\text {V600E }}$}
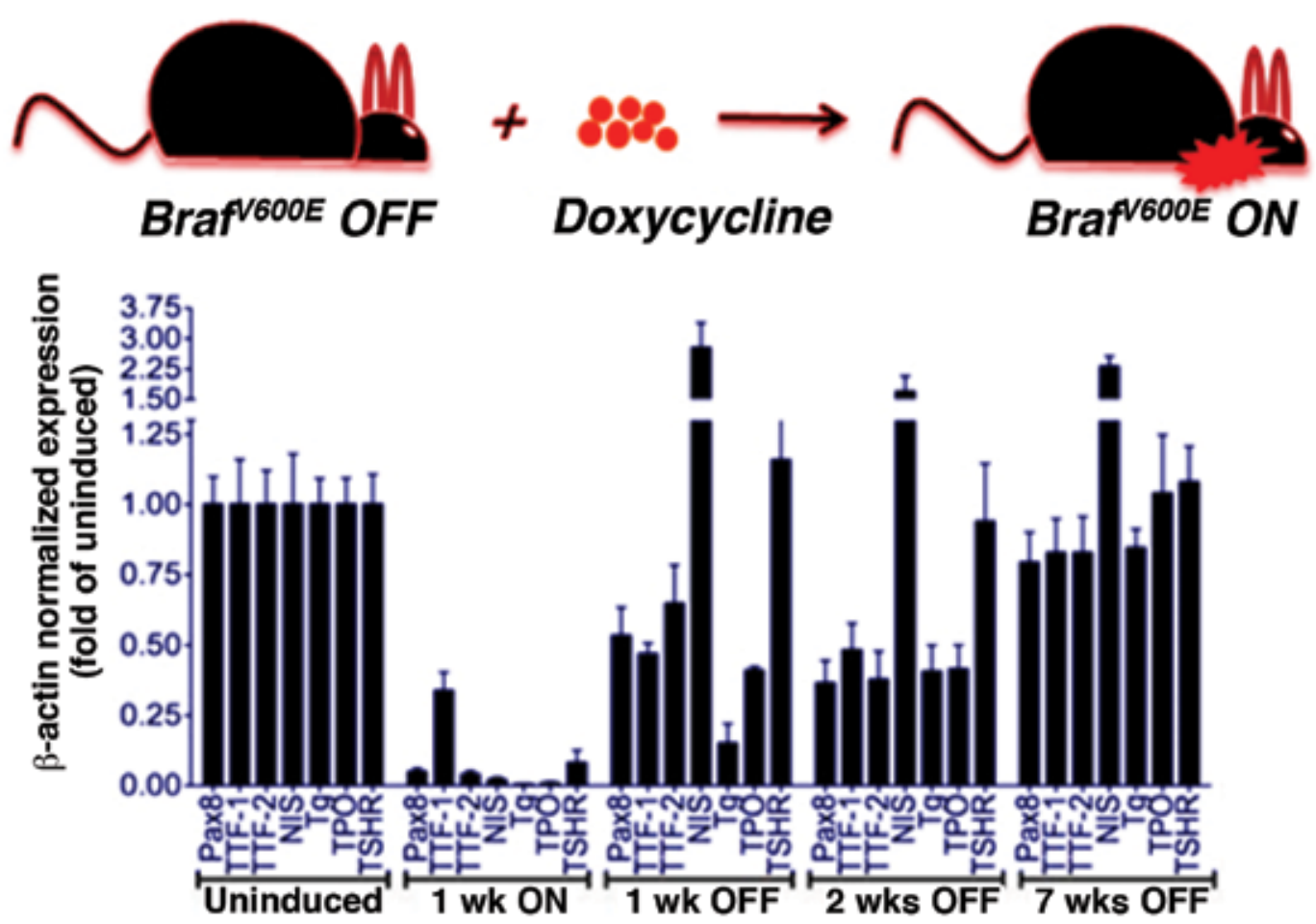

Figure 2. Transgenic mouse model demonstrating the effect of doxycline induction of mutant B-Raft in thyroid cells. Note that within a week of induction of the driver oncogene, the cadre of proteins responsible for uptake of radioiodine are rapidly down regulated, as the effect of the driver oncogene takes hold. If the doxycline is stopped, this effect can be ameliorated, and it is the sodium iodine symporter protein, of $\mathrm{Na}^{+} / \mathrm{I}^{-}$symporter, that responds most quickly (from reference 1). 
is consistent with direct cellular effect, which is not related to clonal selection of sensitive cells, because the maturation occurs too fast and indeed throughout the tumor mass.

There is an increasing awareness that cancers growing in the human body are capable of continuously transforming themselves, often under the pressure of specific treatments, in both fundamental and meaningful ways. This biologic transformation is especially common for patients undergoing treatment with targeted kinase inhibitor drugs (TKIs), whereby during treatment, further evolution of genetic changes may result in resistance to specific antitumor drugs. For example, one of the earliest targeted therapies, imatinib (trade name: Gleevec), was found to be highly effective against chronic forms of myeloid leukemia, due to specific effectiveness through binding to $B C R-A B L$ kinase. The mode of action of imatinib was based on blocking the enzymatic kinase action of this protein. However, resistance developed in many patients through changes in the genetic makeup of the genes encoding BCR$A B L$, resulting in alterations at multiple points in the protein, which in turn nullified the binding action of imatinib. The same process could take place during inhibition of mutant $B R A F$ in thyroid cancer, by drug treatment, and the patient may ultimately escape the effects of therapy.

\section{lodine-124 at Memorial Sloan Kettering Cancer Center}

At MSKCC, we developed positron emission tomography (PET) imaging, as a quantitative molecular imaging tool in the study of thyroid cancer, and one of our earliest efforts was methodology for iodine-124 (124I) production, supported by the Department of Energy (DOE) (Figure 3) (4). We used 124 I as a tool for characterization of targeting and dosimetry of radioantibodies, such as 3F8, an anti-GD2 antibody (5), and A33, an anti-A33 antibody (colon cancer) (6). We and others have also found this radionuclide of special benefit in defining the lesional dosimetry of iodine-131 (131I) therapy in man $(7,8)$. Although 131 I can also be imaged with cross-sectional imaging, using singlephoton emission computed tomography in the post-therapy setting (9) indicates there is little doubt that 124 I and PET imaging can detect more lesions and also quantitate more readily, especially lesions in the $1-2 \mathrm{~cm}$. in diameter range, a size commonly seen in pulmonary metastases. An example of 124 I imaging in man is shown in Figure 3, which shows a reprojection image in a patient with documented thyroid cancer metastatic to the lung, neck nodes as well as to bone.

\section{Re-induction of Therapeutic Levels of Radioiodine Uptake in Metastatic Thyroid Cancer in Man}

In a 20-patient clinical pilot trial, we effectively used quantitative 124 Iodine-Nal PET imaging to estimate individual lesion dosimetry before and after a four-week course of the serine-threonine kinase MEK inhibitor selumetinib (AZD6244) to identify patients who would benefit from additional RAI therapy and to individualize therapeutic dosing recommendations. We demonstrated that selumetinib re-induced iodine uptake in a significant
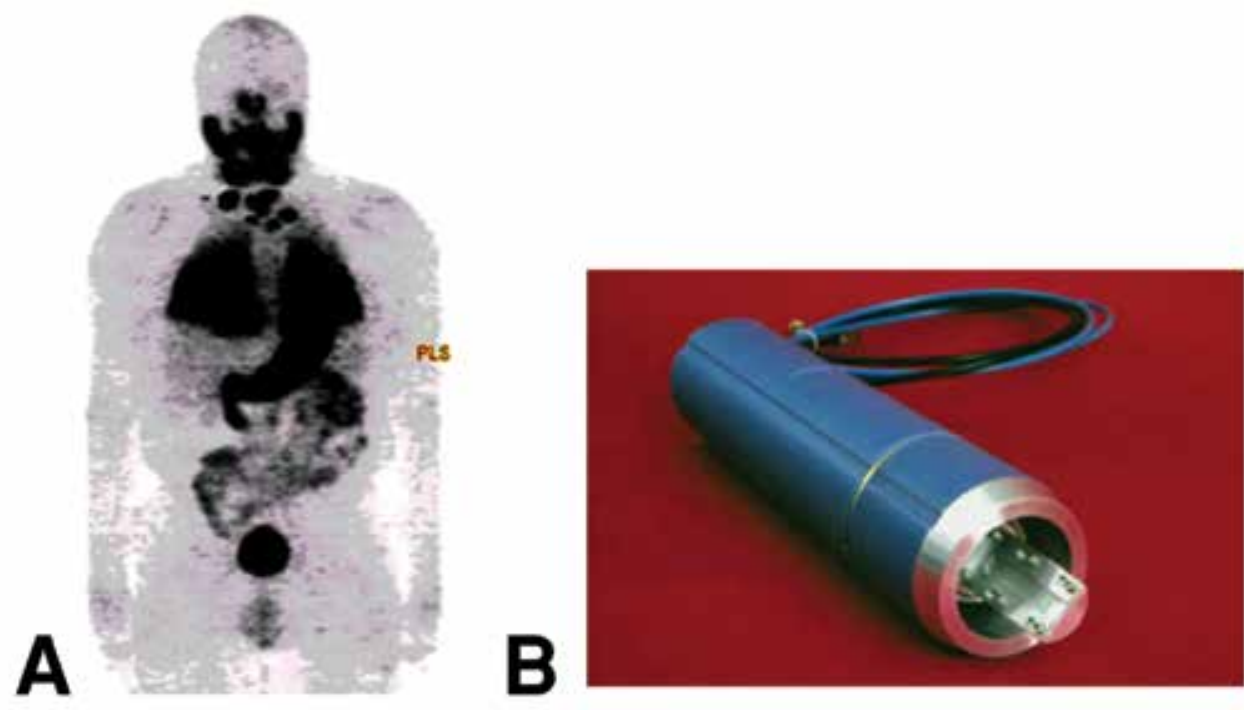

Figure 3. A) Reprojection positron emission tomography imaging in a patient with well differentiated thyroid cancer, metastatic to the lungs, regional neck nodes and also suspected metastases in the scapula and T-12 vertebrae. At the time of imaging, thyroglobulin levels $>11,000 \mathrm{ng} / \mathrm{mL}$; estimated dose from $250 \mathrm{mCi}$ of ${ }^{131}$ I estimated at $>50,000$ cGy; follow-up at 13 years post-multiple 131| treatments (1500 mCi total), TG <0.2, complete clinical response. B) MSKCC (Finn) target system, used to manufacture ${ }^{124}$. Tellurium-124.) $15 \mathrm{MeV}$ protons. ${ }^{124}{ }^{2}$ can be produced in significant quantities by modern hospital and radiopharmacy based cyclotrons 
subset of patients with radioiodine refractory metastatic thyroid cancer (1): 12/20 RAl-refractory patients achieved improved lesional radioiodine uptake with selumetinib therapy. Of those 12 patients, 8 had at least one tumor with 124 l uptake that predicted delivery of $\geq 2,000$ cGy with $\leq 300$ $\mathrm{mCi}$ therapeutic 1311, and went on to experience tumor reductions with therapeutic ${ }^{131}$ I given concomitantly with selumetinib (5 Response Evaluation Criteria in Solid Tumors (RECIST) partial responses, 3 RECIST stable disease). Equally important, the lesional dosimetry also identified a subset of patients in whom high-dose RAI would not be effective, thereby avoiding unnecessary radioiodine exposure. These findings illustrated the potential role of quantitative PET imaging as a tool for documenting drug effects in vivo, and supported the concept that 124 I PET imaging can be used to measure a threshold radiation absorbed tumor dose that will identify patients who will respond to 131। (Figure 4).

\section{The Clinical Problem of Radioactive lodine Treatment of Thyroid Cancer: A Rationale for Lesional Dosimetry}

1311 therapy is widely used in thyroid cancer for thyroid ablation and treatment of metastatic disease. However, the standard approach of using empirical administered activities of 131 I to treat metastatic disease without reliable measurements of lesional dosimetry leads to multiple ineffective RAI treatments in patients subsequently proven to have RAI refractory disease, as well as to sub-optimal dosing even in patients with RAl-avid disease. Since 131। therapy can be associated with significant toxicity (salivary gland damage, lacrimal duct obstruction, and at higher cumulative doses, myelodysplastic syndrome and leukemia), an accurate dosimetry test that predicts whether or not patients will respond to a therapeutic dose of 131 I is sorely needed.
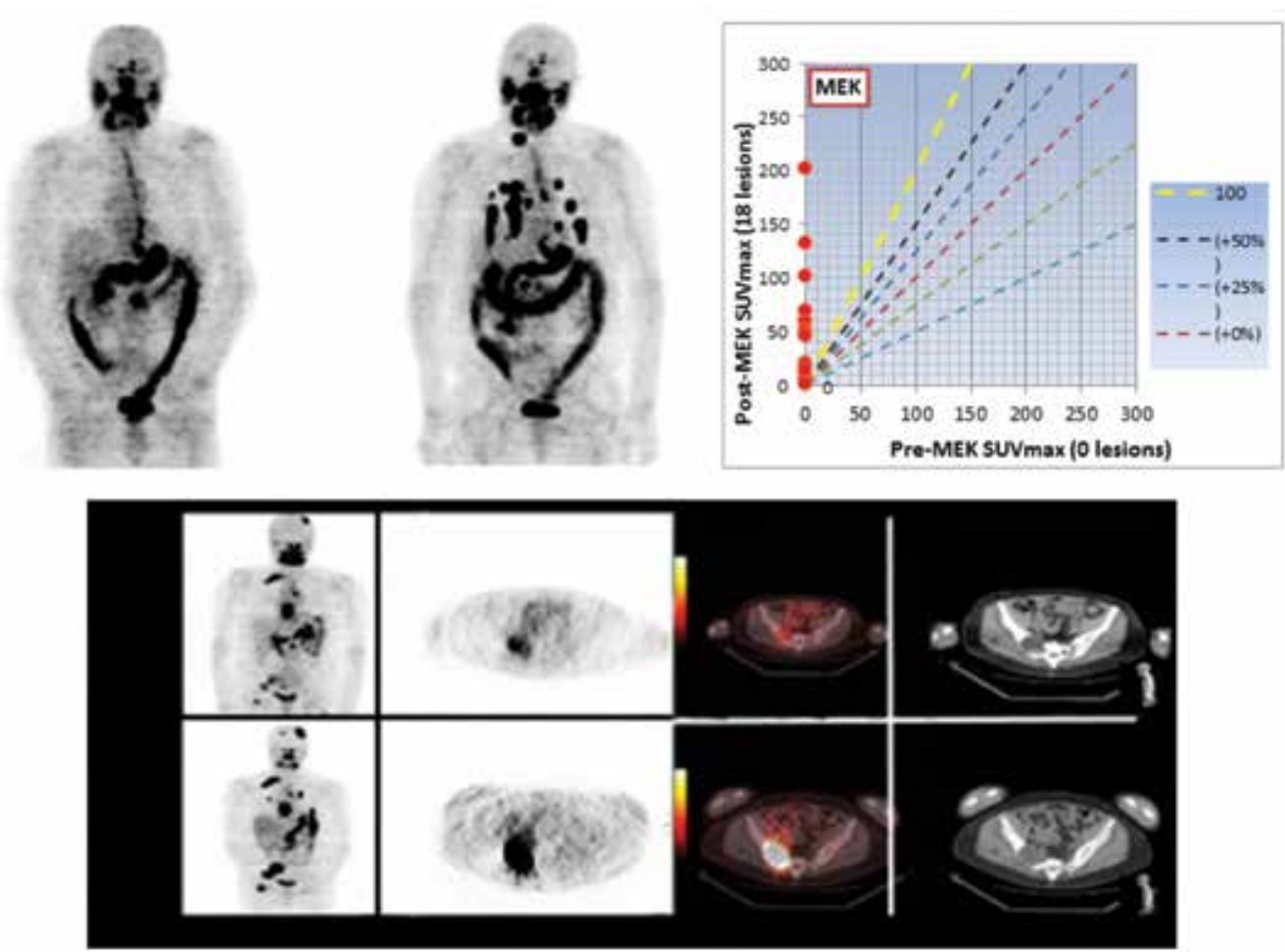

Figure 4. A thyroid cancer patient with widely metastatic neck nodes, pulmonary nodules, mediastinum, and osseous sites. The upper row is the baseline study before seluemetanib treatment (left), and the post four week MEK treatment image showing a number of pulmonary lesions now taking up the radioactive iodine. The graph (top, right) compares the standardized uptake values (SUV) before (abscissa) and after (ordinate) treating in quantitative terms. No lesions were detectable in terms of ${ }^{124}$ | prior to treatment and subsequently, the uptake that developed was seen. There is a different patient showing baseline (upper row) and the re-induction effects of treatment on radioiodine uptake (bottom row). There are new lesions in the lungs and the osseous lesions have greater uptake (left panel coronal image baseline, above and post-treatment below); cross-sectional imaging 124 I imaged on positron emission tomography, baseline (above) and post-treatment (below). There is marked increase in the intensity of uptake in the R. pelvis, and the relationship to computed tomography findings is dramatically displayed in the fusion positron emission tomography/computed tomography, which shows a space occupying lesion in the R. ileum, now with therapeutic levels of uptake. As part of the selumetinib pilot trial, we have been able to document dose-response relationships between ${ }^{124}$ l lesional dosimetry and subsequent structural disease response as determined by Response Evaluation Criteria in Solid Tumors criteria in eight differentiated thyroid cancer patients (1). 
Distant metastases are identified in 10-15\% of patients with differentiated thyroid cancer at some point in the course of their disease. For more than 50 years, RAI has been the mainstay of therapy in these patients (10). However, even in RAl-avid metastatic disease, multiple administrations of RAI are usually required to control the disease. Furthermore, RAI therapy rarely results in clinical remission except in young patients with very small volume, RAl-avid, miliary metastases. The majority of patients with structurally evident RAl-avid distant metastases will have a clinical response marked by either disease stabilization or partial regression of macroscopic disease. Then again, no prospective randomized placebo-controlled studies have established efficacy on progression-free survival or overall survival. Survival rates are less than ideal, with five-year survival rates of $80 \%$ and ten-year survival rates of $55 \%$, even when the distant metastases are RAl-avid (11). Thus, whereas RAI may be an effective treatment in a subset of patients with "RAl-avid" distant metastases, it is seldom curative, and the tools to predict who may benefit and who may not have not been definitively established.

Compared with older series that evaluated responses to therapy on the basis of post-therapy RAI scans and chest radiographs, recent retrospective studies demonstrate that few patients with macroscopic distant metastases have clear-cut RECIST responses when the effectiveness of RAl therapy is assessed with computed tomography or magnetic resonance imaging, or with other modalities such as fludeoxyglucose-PET or the plasma biomarker thyroglobulin $(12,13,14,15,16)$. Furthermore, it is unclear whether the "disease stabilization" seen after RAI is a treatment effect or due to the natural history of insidious growth of well differentiated. RAl-avid metastatic disease (17). It is critically important to determine if inadequate lesional dose is the reason for the relative ineffectiveness of RAI therapy. Recent indications suggest that this may indeed be the case; i.e., pre-treatment with the MEK inhibitor selumetinib prior to RAI therapy dramatically increased the lesional dose in patients with RAl-refractory metastatic thyroid cancer and resulted in a high rate of responses as determined by RECIST criteria (1). Thus, compelling evidence now indicates that inadequate lesional dose is a key limitation to the effectiveness of RAI therapy. Studies designed to quantify, enhance, and optimize lesional dose have become even more critical.

Several approaches to determining lesional dosimetry have been published $(18,19)$ but none of them has gained acceptance into clinical practice outside of a few specialized centers. More recently, 124I-PET has emerged as a potentially clinically applicable methodology for scanning and quantifying lesional dosimetry in differentiated thyroid cancer $(7,20,21)$. While it is clear that whole-body scanning and lesional dosimetry measurements with 124 are feasible, studies correlating 124 l lesional dosimetry with the effectiveness of RAl as measured by cross-sectional imaging (which are needed to define dose-response relationships) have not been conducted.

While lesional dosimetry is a key component of optimal RAI dosing, it is also important to define the maximal tolerable dose that can be administered without complications. Optimal RAI dosing should be based on precise lesional dosimetry (to define an appropriate therapeutic dose), coupled with whole-body dosimetry studies to ensure that the proposed activity can be safely administered without unacceptable side effects. Unfortunately, in clinical practice, the selection of the RAl-administered activity is based far more on its potential toxicity than on the dose likely to be required to achieve a tumoricidal effect.

Over the last 50 years, several empiric dosing regimens that called for fixed doses of RAl at specific intervals have been shown in retrospective studies to be generally well tolerated and often effective $(10,12,22)$. However, recent studies suggest that these empirical dosing recommendations may exceed the maximum safe radiation dose in a significant proportion of older patients with RAl-avid metastatic disease $(23,24)$. In fact, concerns over the frequency and severity of bone marrow and pulmonary toxicity associated with repeated high-dose RAI treatments were expressed in the 1950s and 1960s, which led to the development of dosimetry models to calculate the maximal tolerable activity that can be safely administered without causing excessive radiation exposure to the lungs or bone marrow (25). The value of this approach was recently discussed in a retrospective study demonstrating superior clinical outcomes when RAI therapy was based on whole-body dosimetry rather than empirical RAl dosing $(13,14)$.

The inability to precisely define an optimal treatment activity of RAI means that clinicians cannot tailor treatment recommendations to individual patients. Therefore, some patients are treated with suboptimal doses and do not receive the complete potential therapeutic benefit of RAI. Conversely, some patients receive repeated RAI doses that are ineffective, which unnecessarily expose them to potential side effects. Salivary gland dysfunction, nasolacrimal obstruction, reproductive disturbances, conjunctivitis, and hematological abnormalities can be observed after RAl treatment (26). Although the majority of these side effects are minor and often transient, several studies have demonstrated that high cumulative administered activities of RAI given after traditional thyroid hormone withdrawal can be associated with leukopenia, thrombocytopenia, anemia, and even an increased risk of leukemia with cumulative doses $>300-500 \mathrm{mCi}(27,28)$.

\section{Conclusion}

In conclusion, there is an unmet need for the development of accurate quantitative lesional and whole-body dosimetry that cannot be derived from diagnostic studies with the radioiodine isotopes currently used in practice. 124l dosimetry is the appropriate modality to achieve this, thus 
helping select patients likely to benefit from RAl therapy and sparing all others from unnecessary radiation exposure. Not only is 124 I and PET imaging an exquisite methodology for research project such as ours, there is good reason to believe that 124 | can be made into a practical clinical reagent to replace 131 I for treatment dosimetry.

\section{References}

1. Ho AL, Grewal RK, Leboeuf R, Sherman EJ, Pfister DG, Deandreis $D$, Pentlow KS, Zanzonico PB, Haque S, Gavane S, Ghossein RA, Ricarte-Filho JC, Domínguez JM, Shen R, Tuttle RM, Larson SM, Fagin JA. Selumetinib-enhanced radioiodine uptake in advanced thyroid cancer. N Engl J Med 2013;368:623-632.

2. Chakravarty D, Santos E, Ryder M, Knauf JA, Liao XH, West BL, Bollag G, Kolesnick R, Thin TH, Rosen N, Zanzonico P, Larson SM, Refetoff $\mathrm{S}$, Ghossein R, Fagin JA. Small-molecule MAPK inhibitors restore radioiodine incorporation in mouse thyroid cancers with conditional BRAF activation. J Clin Invest 2011;121:4700-4711.

3. Chapman $\mathrm{PB}$, Hauschild $\mathrm{A}$, Robert $\mathrm{C}$, Haanen JB, Ascierto $\mathrm{P}$, Larkin J, Dummer R, Garbe C, Testori A, Maio M, Hogg D, Lorigan P, Lebbe C, Jouary T, Schadendorf D, Ribas A, O'Day SJ, Sosman JA, Kirkwood JM, Eggermont AM, Dreno B, Nolop K, Li J, Nelson B, Hou J, Lee RJ, Flaherty KT, McArthur GA; BRIM-3 Study Group. Improved survival with vemurafenib in melanoma with BRAF V600E mutation. N Engl J Med 2011;364:2507-2516.

4. Pentlow KS, Graham MC, Lambrecht RM, Daghighian F, Bacharach SL, Bendriem B, Finn RD, Jordan K, Kalaigian H, Karp JS, Robeson WR, Larson SM. Quantitative imaging of iodine-124 with PET. J Nucl Med 1996;37:1557-1562.

5. Larson SM, Pentlow KS, Volkow ND, Wolf AP, Finn RD, Lambrecht RM, Graham MC, Di Resta G, Bendriem B, Daghighian F, et al. PET scanning of iodine-124-3F9 as an approach to tumor dosimetry during treatment planning for radioimmunotherapy in a child with neuroblastoma. J Nucl Med 1992;33:2020-2023.

6. O'Donoghue JA, Smith-Jones PM, Humm JL, Ruan S, Pryma DA, Jungbluth AA, Divgi CR, Carrasquillo JA, Pandit-Taskar N, Fong $Y$, Strong VE, Kemeny NE, Old LJ, Larson SM. 124I-huA33 antibody uptake is driven by $\mathrm{A} 33$ antigen concentration in tissues from colorectal cancer patients imaged by immuno-PET. J Nucl Med 2011;:52:1878-1885.

7. Sgouros G, Kolbert KS, Sheikh A, Pentlow KS, Mun EF, Barth A, Robbins RJ, Larson SM. Patient-specific dosimetry for 1311 thyroid cancer therapy using 124I PET and 3-dimensional-internal dosimetry (3D-ID) software. J Nucl Med 2004;45:1366-1372.

8. Larson SM, Robbins R. Positron emission tomography in thyroid cancer management. Semin Roentgenol 2002;37:169-174.

9. Grewal RK, Tuttle RM, Fox J, Borkar S, Chou JF, Gonen M, Strauss HW, Larson SM, Schöder $H$. The effect of posttherapy 131/ SPECT/CT on risk classification and management of patients with differentiated thyroid cancer. J Nucl Med 2010;51:1361-1367.

10. American Thyroid Association (ATA) Guidelines Taskforce on Thyroid Nodules and Differentiated Thyroid Cancer, Cooper DS, Doherty GM, Haugen BR, Kloos RT, Lee SL, Mandel SJ, Mazzaferri EL, Mclver $B$, Pacini F, Schlumberger M, Sherman SI, Steward DL, Tuttle RM. Revised American Thyroid Association management guidelines for patients with thyroid nodules and differentiated thyroid cancer. Thyroid 2009;19:1167-1214.

11. Durante $C$, Puxeddu $E$, Ferretti E, Morisi R, Moretti S, Bruno R, Barbi F, Avenia N, Scipioni A, Verrienti A, Tosi E, Cavaliere A, Gulino A, Filetti $S$, Russo D. BRAF mutations in papillary thyroid carcinomas inhibit genes involved in iodine metabolism. J Clin Endocrinol Metab 2007; 92:2840-2843.

12. Durante $C$, Haddy N, Baudin E, Leboulleux S, Hartl D, Travagli JP, Caillou B, Ricard M, Lumbroso JD, De Vathaire F, Schlumberger M.
Long-term outcome of 444 patients with distant metastases from papillary and follicular thyroid carcinoma: benefits and limits of radioiodine therapy. J Clin Endocrinol Metab 2006;91:2892-2899.

13. Klubo-Gwiezdzinska J, Burman KD, Van Nostrand D, Mete M, Jonklaas J, Wartofsky L. Radioiodine treatment of metastatic thyroid cancer: relative efficacy and side effect profile of preparation by thyroid hormone withdrawal versus recombinant human thyrotropin. Thyroid 2012;22:310-317.

14. Klubo-Gwiezdzinska J, Burman KD, Van Nostrand D, Mete $M$, Jonklaas J, Wartofsky L. Potential use of recombinant human thyrotropin in the treatment of distant metastases in patients with differentiated thyroid cancer. Endocr Pract 2013;19:139-148.

15. Sabra M, Tuttle RM. Recombinant human thyroid-stimulating hormone to stimulate 131-I uptake for remnant ablation and adjuvant therapy. Endocrine Prac 2013;19:149-156.

16. Sabra MM, Dominguez JM, Grewal RK, Larson SM, Ghossein RA, Tuttle RM, Fagin JA. Clinical outcomes and molecular profile of differentiated thyroid cancers with radioiodine-avid distant metastases. J Clin Endocrinol Metab 2013;98:829-836.

17. Sabra MM, Grewal RK, Tala H, Larson SM, Tuttle RM. Clinical outcomes following empiric radioiodine therapy in patients with structurally identifiable metastatic follicular cell-derived thyroid carcinoma with negative diagnostic but positive post-therapy 1311 whole-body scans. Thyroid 2012;22:877-883.

18. Maxon HR, Thomas SR, Hertzberg VS, Kereiakes JG, Chen IW, Sperling MI, Saenger EL. Relation between effective radiation dose and outcome of radioiodine therapy for thyroid cancer. N Engl J Med 1983;309:937-941.

19. Van Nostrand D, Atkins F, Yeganeh F, Acio E, Bursaw R, Wartofsky L. Dosimetrically determined doses of radioiodine for the treatment of metastatic thyroid carcinoma. Thyroid 2002;12:121-134.

20. Erdi YE, Macapinlac H, Larson SM, Erdi AK, Yeung H, Furhang EE, Humm JL. Radiation Dose Assessment for 1-131 Therapy of Thyroid Cancer Using I-124 PET Imaging. Clinical Positron Imaging 1999;2:41-46.

21. Freudenberg LS, Jentzen W, Petrich T, Frömke C, Marlowe RJ, Heusner T, Brandau W, Knapp WH, Bockisch A. Lesion dose in differentiated thyroid carcinoma metastases after rhTSH or thyroid hormone withdrawal: 124I PET/CT dosimetric comparisons. Eur J Nucl Med Mol Imaging 2010;37:2267-2276.

22. Tuttle RM, Ball DW, Byrd D, Dilawari RA, Doherty GM, Duh QY, Ehya H, Farrar WB, Haddad RI, Kandeel F, Kloos RT, Kopp P, Lamonica DM, Loree TR, Lydiatt WM, McCaffrey JC, Olson JA Jr, Parks L, Ridge JA, Shah JP, Sherman SI, Sturgeon C, Waguespack SG, Wang TN, Wirth LJ; National Comprehensive Cancer Network. J Natl Compr Canc Netw 2010;8:1228-1274

23. Kulkarni K, Van Nostrand D, Atkins F, Aiken M, Burman K, Wartofsky L. The relative frequency in which empiric dosages of radioiodine would potentially overtreat or undertreat patients who have metastatic welldifferentiated thyroid cancer. Thyroid 2006;16:1019-1023.

24. Tuttle RM, Leboeuf R, Robbins RJ, Qualey R, Pentlow K, Larson SM, Chan CY. Empiric radioactive iodine dosing regimens frequently exceed maximum tolerated activity levels in elderly patients with thyroid cancer. J Nucl Med 2006;47:1587-1591.

25. Benua RS, Cicale NR, Sonenberg M, Rawson RW. The relation of radioiodine dosimetry to results and complications in the treatment of metastatic thyroid cancer. Am J Roentgenol Radium Ther Nucl Med 1962;87:171-182.

26. Lee SL. Complications of radioactive iodine treatment of thyroid carcinoma. J Natl Compr Canc Netw 2010;8:1277-1286.

27. Brown AP, Chen J, Hitchcock YJ, Szabo A, Shrieve DC, Tward JD. The risk of second primary malignancies up to three decades after the treatment of differentiated thyroid cancer. J Clin Endocrinol Metab 2008;93:504-515.

28. Rubino $C$, de Vathaire F, Dottorini ME, Hall P, Schvartz C, Couette JE, Dondon MG, Abbas MT, Langlois C, Schlumberger M. Second primary malignancies in thyroid cancer patients. $\mathrm{Br} J$ Cancer 2003;89:1638-1644. 